\title{
Kurgusal Yapı ve Tematik Açıdan Her Çi Beno Sanıke (Her Şey Masal Olur) Romanı
}

\section{ilyas AKMAN}

Öz: Bu çalışmada, Sait Çiya'nın 2001 yılında basılan ve Zazaca yazıımış ikinci roman olma özelliğine sahip Her Çi Beno Sanıke adlı eseri, kurgusal yapı ve tematik açıdan analiz edildi. Edebî eserlerde yapı kavramı kişi, yer, zaman, anlatıcı, kurgu ve benzeri unsurlardan oluşan geniş bir muhtevayı barındırır. Makalede, konunun daha spesifik ve ayrıntılı ele alınabilmesi için yapı unsurlarından sadece kurgusal yapı konusu ele alındı. Bu konu üzerinde duruldu çünkü romanın kurgusal yapısı, alışıımış yapıların dışındadır ve eseri okumaya başlayan okurun ilk dikkatini çeken hususlardan biridir. Tematik açıdan ise sürgünlük, anadile özlem, çeşitli tarihi olaylar ile masalların, halk anlatılarının önemli motiflerinin yazar tarafından işlendiği tespit edildi.

Anahtar Kelimeler: Zaza Dili ve Edebiyatı, Sait Çiya, Her Çi Beno Sanıke.

\section{The Novel 'Her Çi Beno Sanıke (Everything Could Be Tale)' in the Context of the Fictional Structure and Theme}

Abstract: Published in 2001 and taken place as the second novel in Zazaki/Zazaish language, the novel 'Her Çi Beno Sanıke (Everything Could Be Tale)' has been analyzed in terms of fictional structure and thematic in this study. In literary works, the concept of structure contains a wide range of contents such as character, place, time, narrator, the way the events are constructed and so on. Only the fictional structure issue was discussed from the structural elements, aiming to analyse the subject more specifically and detail in the article. The fictional structure has been focused as because the fictional structure of the novel is unlikely to the usual structures as well as this is one of the first things that attract the reader's attention. On the other hand, exiles, longing for mother tongue, as well as some historical events are worth mentioning in the thematic aspect.

Yrd. Doç. Dr., Mardin Artuklu Üniversitesi, Edebiyat Fakültesi, Kürt Dili ve Edebiyatı Bölümü, ilyasakman@hotmail.com. 
Keywords: Zazaki/Zazaish Language and Literature, Sait Çiya, Her Çi Beno Sanıke (Everything Could Be Tale).

\section{Giriş}

Her Çi Beno Sanıke, Sait Çiya'nın 2001 yılında basılan romanıdır. Eser, Zazaca yazılmış olan ikinci romandır. Bu dildeki ilk roman, Deniz Gündüz tarafından yazılmıştır. Onun 2000 yılında basılan Kilama Pepûgî (Guguk Kuşunun Şarkısı) adlı eseri, Zazaca yazılan ilk romandır. 2000 yılından sonra on üç tane Zazaca roman kaleme alınır ve ifade edildiği gibi Çiya'nın romanı bunlardan biridir. Bu on üç roman üzerine yapılan bilimsel çalışmalar son derece azdır. Her Çi Beno Sanıke romanı hakkındaki bu makale, Zaza romancılığı alanındaki literatüre katkı sunmak için kaleme alındı.

Roman, kurgusal yapı ve tematik unsurlar ekseninde analiz edildi. Bir edebî eserin nasıl kurgulandığı, onun yapısal özelliklerinin en önemli sacayaklarındandır. Kişi, yer, zaman, anlatıcı gibi unsurlar, öteki önemli yapısal özellikler. Biz ise çalışmamızda, yapısal özelliklerden sadece, eserin nasıl kurgulandığı üzerinde durduk. Eserin kurgusu, alışılmış yapıların dışındadır ve eseri okumaya başlayan okurun ilk dikkatini çeken hususlardan biridir. Bu nedenle, bu konunun detaylı olarak analiz edilmesine önem verdik ve dikkatimizi ona yönelttik. Bu yapısal özelliğin yanında eserde dikkati çeken temaları da ortaya koymaya çalıştık.

\section{Kurgusal Yapı}

Romanın kurgulanma biçimi, geleneksel yöntemlerin dışındadır. İki sesin karşılıklı konuşmaları, tartışmaları, sırdaşlık yapmaları üzerine bir kurgu söz konusudur. Önce sözü, karakterlerden biri alır (o aynı zamanda anlatıcıdır) ve düşüncelerini dile getirir, ondan sonra ise öteki kişi sözü alıp ona cevap verir. Bu iki sesin diyalogu ise zaman zaman, açılan parantezlerle kesilir. Anlatıcı konumundaki ilk ses, bu parantezlerle âdeta ikinci bir misyonu yani üst-anlatıcı misyonunu da yüklenir. O, açılan parantezlerin içinde, kendi düşüncelerini daha ayrıntılı olarak ve romanın hangi yöne doğru evrileceği bilgilerini verir. Bu yöntem daha önce başka edebiyatçılarca da kullanılmıştır. Örneğin, Zaza edebiyatında Jêhatî Zengelan, Zifqêra Berî (Kapı Eşiği) adlı romanında; Türk edebiyatında da Ferit Edgü Kimse romanında, bu yönteme başvurmuştur. Zengelan'ın ve Edgü'nün romanları da iki sesin karşılıklı konuşmaları eksenine dayanır. Kurgunun yanında, içeriksel benzerlikler de vardır. Her üç romanda da sürgünlük temel izleklerdendir. Edgü'nün Kimse romanı, Hakkâri'ye sürgüne gönderilen bir öğretmenin hayatının anlatıldığı Hakkâri'de Bir Mevsim romanının devamıdır ve sürgünlük başat konulardandır. Öte yandan Zengelan'ın romanında, topraklarını terk etmek zorunda kalıp İstanbul, Almanya gibi yerlere göç eden Kürtler söz konusu edilir.

Zengelan'ın eserinde yaşanılanlar, birbirine âşık olan bir erkek ve kadının bakışları üzerinden anlatılır. Bu dile getiriliş de her iki karakter sohbet ediyormuş 
edası içinde vücut bulur. Genelde, her ikisinin sözleri ayrı bölümler şeklinde verilse de vurgulandığı gibi sohbet havası söz konusudur. Şu satırlar örnek gösterilebilir:

"Ellerin ellerimdeydi. Ellerin, aşkın ve sevmenin sıcaklığını bana verip gönlümü ısıttı/Destê to destê mi de bi. Germineya evin û heskerdişî day mi, zerrîya mi germin kerd destê to.

$* * *$

Ellerimi tuttuğun vakit, beni her türlü sıkıntıdan uzak tutup sahipleneceğini anladım/Wexto ke to destê mi tepișt, mi bawer kerd ke ti mi miqat kenî, mi talûkan ra pawenî, wayîrê mi vejîyenî” (Zengelan, 2009: 11). Önce sözü erkek alır ve ilk el ele tutuştukları anda neler hissettiğini dile getirir. Ardından, bu anlar, kadının bakışı üzerinden verilir. Ancak bunlar, bir sohbet edasında gerçekleşir. Romanın devamında ise erkek, yaşadıkları politik olayları, sürgünlük gibi konuları dile getirecektir. Ancak bu politik konuların anlatıldığı bölümlerde de kadın konuşmaya devam eder ve sohbet edası sürdürülür. Kadın, onun anlattıklarının kendi ruhunu nasıl yaraladığını aktarır.

Edgü ile Çiya'nın eserleri arasındaki paralellikler ise şu örnekler üzerinden somutlaştırılabilir. Edgü'nün romanında, iki sesin karşılıklı konuşması, çoğu zaman birbirine muhalefet etme, birbirinin zıddı şekilde evreni telakki etme biçiminde vücut bulur. Şu pasaj örnek olarak verilebilir: "Günün batışı ne kadar korkunç burada, diyor Birinci Ses. Fakat çok güzel doğuyor, diyor İkinci Ses" (Edgü, 2006: 86). Burada, birinci ses ile ikinci sesin karşılıklı konuşması ve farklı fikirlerini dile getirmeleri söz konusudur. Birinci sesin olumsuz bakışına karşılık ikinci sesin olumlu yaklaşımı aktarılır. Şu sözler ise sürgünlüğe vurgu yapar: "Sürgünlük günlerini ansıyor musun? diyor Birinci Ses. Ansımak mı? Yaşıyoruz ya, diyor İkinci Ses” (Edgü, 2006: 57). Sürgünlüğü derinlemesine yaşayan birinin hayatı, bu yöntemle romanda anlatılır. Her Çi Beno Sanıke romanı da benzer tarzda vücuda getirilmiştir.

Romanda iki sesin, çoğu kez birbirinin zıddı yorumlar dile getirdikleri diyalogları söz konusudur. Zaten eserde, bu durum doğrudan da dile getirilir: "Metin, bu konuşma üzerine kurulmuştur... Kiminle konuştun diye sorulabilir?... Doğrusunu söylemek gerekirse ben de bilmiyorum. Belki de kendi kendimle konuştum/Bıngê na nustey, na qeseykerdenu ra veciya... Beno ke pers kenê, to kam de qesey kerd?... Eke raştiye pers kenê, ez ki nêzan. Belka ki mı xo-xode qesey kerdo " (Çiya, 2001: 10). Bu konuşmada, neredeyse tek bir konuda bile aynı şekilde düşünmezler. İki ses, sürekli olarak bir çatışma içindedirler. Romanda da ifade edildiği gibi, bu öteki/ikinci sesin, anlatıcının/yazarın kendi bilincinin bir başka parçası olduğu söylenebilir. Bütün insanlar, birçok konuda, çeşitli düşünceler arasında gidip geldikten sonra kararlarını verirler. Öteki sesin, bilincin farklı alternatifler/düşünceler sunan başka bir kısmı olduğu dile getirilebilir. Tabi 
bu sesin, toplumda, anlatıcı/yazar gibi düşünmeyen kişilerin temsilcisi olduğu da ifade edilebilir.

Bu seslerin birbirine muhalefetleri, temel olarak, hayatın kavranışı üzerinedir. Illk ses, tarihe yönelen, tarihte yaşanmış olan acıları dile getiren biridir. Bu kötü yaşanmışlıklardan muzdariptir ve kendisine göre böyle düşünerek, yaşayarak tarihin sırtına yüklemiş olduğu görevini yerine getiriyordur. Sartre, "yazarın görevi de hiç kimsenin dünyadan habersiz kalmamasını ve bu yüzden kendisinin suçsuz olduğunu ileri sürememesini sağlamaktır” (Sartre, 2005: 33) der. Anlatıcı ve tabi ki yazar, Sartre gibi düşünmekte ve tarihin, sırtına yüklediği görevi yerine getirme çabasına girmektedir. Ancak öteki ses, onun bu yönteme başvurarak gerçeklikten uzaklaştığını iddia eder. Romanın anlatıcısı birinci ses, yazı âlemine, tarihi konulara değinince öteki ses, onun gerçeklikten uzaklaştığını ve gerçeklik ile masalın birbirinden ayrı şeyler olduğunu vurgular. Ancak onun cevabı şu olur: "Burada gerçekleşmemiş hiçbir şey yoktur. Burada gerçeklikten söz ediliyor/Naca de çiyo de nêbiyae çino. Naca de raştiye qesey kena” (Çiya, 2001: 19). Gerçeklik ve hayal üzerine olan tartışma, romanda önemli bir yer tutar. İki ses, roman boyunca, çeşitli olaylardan hareketle bunun mücadelesini verirler.

Bu iki sesin anlaşamadıkları konulardan biri de Dersim olaylarıdır. Öteki ses, bu konuda, birinci sese muhalefet eder. Dersim olaylarından çok fazla söz edilince, öteki ses şunları söyler: "Herkes kendi dertlerine ağlayıp ötekilerin acısını görmezse insanlık ne anlama gelir?/Her kes ke derdê xorê bıberbo, dert u khulê bini mevino, o zaman mordemiye yena çı mane?" Bunun üzerine ilk ses şu cevabı verir: "Kendi derdine ağlamayan yabancının derdine de ağlayamaz/Uyo ke derdê xorê nêberbeno, nêşikino ke derdê sarri rê bıberbo” (Çiya, 2001: 44). Bu konu üzerine olan tartışmaları, roman boyunca sürer. Hemen hemen her konuda farklı düşüncelerini dile getirerek romanı bitirirler. Zaten romanın sonunda bu farklı düşünme, doğrudan dile getirilir. Öteki ses, şunları söyler: "Sözümüz aynı olmuyor!... Benim için dünya, her gün yeniden başlıyor. Hiçbir şey bitmiyor. Benim ki neşe ve keyiftir seninki yastır/Vatena ma ju nêbena!... Serba mı dina her roc newe de sıfte kena. Qe ju çi ki nêqedino. Ê mi şên u şênatiya, ê to şin û şıvano" (Çiya, 2001: 123). Bu ifadeler ile öteki ses, ikisi arasındaki temel farklılığı ortaya koyar. Illk ses için hayat; yaşanmış kötü deneyimleri unutmamak, onların yasını tutup zihinlerde taze tutmaktır. Ancak öteki ses ise hayatın neşeli, keyifli yanlarını görmeye meyillidir.

Romanın kurgusunda dikkati çeken öteki bir nokta da daha önce de vurgulandığı gibi birinci sesin, üst-anlatıcı olarak zaman zaman parantez açıp koyu siyah renge büründürülmüş ifadelerle çeşitli açılamalarda bulunmasıdır. Bu açıklamalarıyla o, romanın yönünün nereye doğru evrileceğini açık eder. Örneğin bir bölümde, münakaşalarının değerlendirmesini yapar ve romanın nereye doğru kayacağını belirtir. Burada güncel konularda anlaşamadıklarını bu yüzden romanın konusunu, tarihi konulara doğru evriltebileceğini ifade eder: "Bugünün hengamesinden kurtulup dikkatimizi eski zaman günlerine vereceğiz/Ma ke 
hengamê ewroyêni ra xo ranêreyna, balê xorê rocunê khanu ser şime" (Çiya, 2001: 35). Nitekim öyle de olur ve bu bölümden sonra, Dersim olayları ayrıntılı olarak anlatılır.

Yazar, kurguyu oluştururken alımlama estetiğine de başvurur ve okuru, eserinin bir yazarı olmaya davet eder: “Okuyun, bakın, eğer eksik ya da yanlış bir şey yazılmışsa düzeltin. Tekrardan yazın/Bıwanê, niadê, eke çiyê kêmi nuşiyo, ya ki çewt nuşiyo, rast kerê. Reyna bınusnê" (Çiya, 2001: 10). Bu ifadeler, alımlama estetiğinin düşüncesini ifade eder. Alımlama kuramı düşüncesinde, eser sadece bir davetiyedir, bir ipucudur (Eagleton, 2011: 89). Okuru esere davet eden yazar, eserinde boşluklar bırakır ve okur da o boşlukları kendisine göre doldurarak, onu yeniden yazar (Aytaç, 2009: 155). Çiya eserinde, bu kuramı doğrudan dile getirerek okurlardan eserini yeniden yazmalarını ister. Zaten tartışmaların çoğu bir noktaya vardırılmaz ve bu şekilde eserde boşluklar bırakılır. Yazar, okurların bu boşlukları kendilerinin doldurmasını ve eserini yeniden yazmalarını bekler.

\section{Romanın Tematik Yapısı}

\subsection{Dehlize Dönen Sürgünlük ve Memleket Özlemi}

Sürgünlük ve memleket özlemi, romanın öne çıkan izleklerindendir. Hatta roman, doğrudan bu duyguların dile getirilmesi ile başlar: "Yollarım daralıyordu, boğuluyordum.” Bu ifadeler, romanın ilk satırlarında geçer. Okuyucu, romana başlar başlamaz, memleket hasreti ile yanan, yabancılık psikolojisi ile bunalmak üzere olan roman karakteri ile karşılaşır. Bu karakter, kendi ata topraklarından göç etmek zorunda kalan biridir. Almanya'da sürgün hayatı yaşamaktadır. Ancak sürgünde geçirdiği her gün onu biraz daha bunaltmış ve en nihayetinde psikolojik boğulma aşamasına gelmiştir: "Almanya'da geçen her an, yollarım daralıyor, boğulacak hale geliyordum/Almanya de her ke şiyêne roe mı biyêne teng, ez fatasiyêne" (Çiya, 2001: 5). Bu, âdeta göçmenlerin birçoğunun yaşamaya mahkûm olduğu bir durumdur. Ekși'nin de vurguladığı gibi, göçmen, bir yandan yeni kültür tarafından yok edilecekmiş korkusunu yaşarken öte yandan bireyselliğini sürdürmek ister. Kimliğini koruyup kendisi olduğunu hissetmesi son derece önemlidir. Bu çatışmalar onda yabancılaşma ve karmaşa yaratırken, kimliğinin değişik yönleri arasında çatışmalar baş gösterir ve yalnızlık, izolasyon duyguları depresif eğilimleri çoğaltır, şiddetlendirir. Bu güçlüklerle başa çıkamadığı zaman çatışmalar yer değiştirebilir, psikosomatik bozukluklar ortaya çıkar (Ekşi, 2002: 218). Romanın karakteri de dile getirilen psikolojik durumları yaşar. O, yabancısı olduğu bu ülkede yol alırken bilinmeze doğru gitmekte ve arkasında bıraktığı tüm geçmiş yaşamını hasretle yad etmektedir. Bu yol alma; ona geçmişini, toprağını unutturmak bir yana tüm bunları zihninin birincil öğesi haline getirir.

Alışması gereken yeni yaşam alanı Almanya; nefes almasını güçleştiren, baş edilmesi güç yabancılık hissiyle dolmasına neden olan bir dehlize dönmüştür. Bu dehliz, âdeta Bilge Karasu'nun hikâyesindeki dehlizi andırır. Karasu'nun 
“Dehlizde Giden Adam” öyküsünde karakter, bilmediği bir dehlize girer ve hayatının kâbusunu yaşar. Orada karakter zaman ve mekân dengesini yitirir, zihni allak bullak olur. En sonunda da görme yetisini kaybeder: "Sonra göremedi artık deliği. Kör olduğunu anladı. Durdu. Geri dönse, karanlığa dalsa, gözleri yeniden açılır mıydı?" (Karasu, 2006: 101). Çiya'nın romanının karakteri de Karasu'nun karakterini andırır. Almanya, Çiya'nın roman karakteri için Karasu'nun öyküsündeki dehlize dönmüştür. Roman karakterinin yaşam dengesi, Almanya'da darbe alır. Zaman ve mekân, onun dünyasında normal bir insanın ki gibi akmaz. Zaten bu durum, sürgünlüğün doğasında vardır. Öte yandan nasıl ki Karasu'nun öykü karakteri, gözlerini kaybeder, Çiya'nın roman karakteri de boğulma aşamasına gelir. Boğulmak üzeredir; çünkü yeni ülke, onu mutlu etmediği gibi kendi ülkesini ona hatırlatan kıvılcımlar gönlüne, zihnine çarpmakta ve geçen her gün, memleketinden ne kadar uzak düştüğünü düşünüp durmaktadır. Mekânsal uzaklık, zihin dünyasında devasa bir boşluk oluşturur. Bu boşluk onun için bir kara deliğe dönmekte ve o, her geçen gün biraz daha bu kara deliğin derinliklerine çekilmektedir.

Bu konu, romanda o kadar önemlidir ki romanın bölümlerinden birinin ismi “Vatansızlık”tır. Roman karakteri, vatansızdır çünkü vatanı ona yasaklanmıştır: "Memleketim bana yasaklanmıştı. Çocukluğumun geçtiği; sokaklarında, taşlarında, nehirlerinde, dağlarında, tepelerinde dolaştığım; her yerinde benden izler bulunan yerler bana yasaktı/Welatê mı mırê yasax bi, tomete bi. Cao ke domantiya mı vêrdi bi ra, cao ke ez kemer u kuçu de, dere u derxunu de, ko u gerisu de feteliay bi, cao ke her vizoyê xo sero mıra ju rêçe esti bi, nıka mırê yasax bi " (Çiya, 2001: 9). Vatansızlık adlı bölümde karakter, kendi durumunun dramatikliğini ortaya koymak için gurbetlik ve sürgün arasındaki fark üzerinde durur.

Roman karakteri, yaşadıklarının gurbetlik değil sürgün olduğunu dile getirir. Gurbetin, memleket sevgisini büyüttüğünü ancak sonunda kavuşmanın söz konusu olabileceğini ifade eder. Gurbetlikte, bireylerin de sonuca etki edebildikleri ve hasretin sona erebileceği vurgulanır. Ancak sürgün öyle değildir. Ona göre, sürgünde, bireyin eli kolu bağlıdır. Artan memleket sevgisini dindirmek çok güçtür; çünkü birey, bu konuda sonuca etki edemez. Anlatıcı, bu yüzden, sürgünün dermanının olmadığını söyler. Bu yorumları üzerine öteki ses, onu biraz daha normal düşünmeye davet eder ancak o, "sürgünlüğün kendisi normal değildir, bir hastalıktır. Sürgünün kendisi hastadır, yaralıdır/Surgıniye normal niya ke jê nêweşiyewa. Surgın be xo ki ju nêweso, dırbetıno" (Çiya, 2001: 32) sözlerini söyleyerek düşündüklerinin, yaşadıklarının kaçınılmaz olduğunu vurgular. Roman karakterinin, sürgünü, hastalıkla beraber tanımlaması, önemli bir noktayı ortaya koyar. Birçok aydın, dilin metaforik dünyasını kullanarak, sürgünü, hastalıkla beraber adlandırır. Edward Said bunlardan biridir. Said, sürgünü cüzzamlı olmakla eş değer görür (Said, 2009: 53). Çünkü sürgüne gönderilen kişinin yeni toplumu tarafından kabul görmesi kolay değildir. Belli bir süre bu kişi, cüzzamlı muamelesine tabi tutulur ve ondan uzak durulur. Anlatıcının, sürgüne ve yaşadığı 
sorunlara dair sözleri üzerine, öteki ses, "dert varsa derman da vardır" diyerek onu sükûnete davet eder. Ancak o, "umut, fakirin ekmeğidir fakat fakir hep açtır. Sorunların karşısında kaçıyorsun. Sorunların ağırlığını görmek istemiyorsun" diyerek ona itirazlarını yükseltir. Bundan sonra da "heimatlos (Almanca, evsiz, yurtsuz demek) nedir bilir misin? Dur sana anlatayım” der. Vatansızlıkta, kaybedilen çocukluğun ve bütün bir geçmişin olduğunu aktarır. Öyle ki ataların mezarını görmek dahi artık imkânsızdır (Çiya, 2001: 33). Tüm bunların da ortaya koyduğu gibi roman karakteri, sürgünlüğün girdaplarında debelenmekte ve memleket hasretiyle yanmaktadır.

\subsection{Dil Olgusu ve Adaptasyon Sorunu}

Roman karakteri, hayatı boyunca dil sorununu yaşadığını dile getirir. Çift katmanlı dil sorunu konusu işlenir. Çocuğunun okulunda veli toplantısı olunca kalkıp oraya gider. Ancak Almancası iyi olmadığı için öğretmeni anlamakta zorlanır. Bu tablo onu çocukluğuna götürür. Okulun ilk gününde neler yaşadıklarını hatırlar. Öğretmen karşılarına geçip konuşur ancak öğrencilerin büyük çoğunluğu onu anlamaz. Anlamsız ve boş gözlerle ona bakıp dururlar. Ders sonunda öğretmen yüksek ve açık şekilde "yarın erken gelin" der. Öğrencilerin iyi anlamadıklarını görünce "erken, erken, erken” diye tekrarlar. Eve yetiştiklerinde aileleri, okulda ne öğrendiniz diye sorduklarında, onlar da öğretmenin “erken” gibi bir kelime kullandıklarını söylerler. Aileler ise olsa olsa öğretmen "örken” kelimesini kullanmıştır diye düşünürler. Sonraki gün öğretmen, birçok öğrencinin iple okula geldiğini görünce şaşırır. Türkçeyi az da olsa bilen öğrencilerden olayın sebebini anlar. Çocuklar, öğretmenin ne dediğini tam anlayamadıklarından ailelerine de durumu tam anlatamazlar. Aileler de erkene benzeyen kelimenin örken yani ip olduğunu düşünüp öğretmenin ipe ihtiyacı olduğunu sanırlar ve çocuklarıyla ip gönderirler (Çiya, 2001: 25). Almanya'da çocuğunun öğretmeni karşısında olan romanın anlatıcısı, bu anıları düşünür ve şu anda da benzer bir durum yaşar. Öğretmeni iyi anlamıyordur. Bu yüzden öğretmen, sorusu olan var mı? diye sorduğunda, eski anılarını da düşünüp korkudan ağzını açamaz. Gerek onun ve ailesinin, gerekse de onlar gibi olan diğer ailelerin dil tecrübeleri çok trajiktir. Okullar, dil tecrübesinin dramatik boyutunun en fazla görüldüğü alanlardan biridir. Zaten göçmenlerin okul deneyimi, her zaman için trajik, dramatik olmuştur. Tezcan'ın vurguladığı gibi Almanya'ya göç eden ailelerin çocukları, okul adaptasyonunda son derece zorluk çekerler. Onlar, hazırlık sınıflarından normal okula geçmede ciddi sorunlar yaşarlar. Hazırlık aşamasını bir türlü rahatlıkla geçemezler ve bu aşamada normalden birkaç yıl fazla kalırlar. Normal okula geçişte de benzer sorunlar devam eder. Aynı sınıfta 45 yıl kaldıkları olur. Hatta bazıları, zorunlu eğitim yıllarını söz konusu sınıflarda tamamlayarak sertifika alamadan okullaşma yaşının dışına çıkarlar (Tezcan, 2000: 20).

Karakter, "dil, insanın vatanıdır" sözüne atıfta bulunduktan sonra, dil eksenli deneyimlerini anlatmayı sürdürür. İşe giderken, tramvaya binerken, 
topluluklarda bulunurken binlerce dile denk geldiğini söyler. Bu anlarda, kendi diline denk gelip gelmeyeceğine merak ettiğini ve konuşmalara kulak kabarttığını ifade eder. Ancak kendi dilinden tek kelime duymaz. Bu durumu, Nuh tufanına benzetir. Onun için sanki Nuh tufanı olmuştur ve kendi dilini konuşan tüm insanlar orada can vermişlerdir (Çiya, 2001: 11). Bu anlarda bunaldığını ve kendisini kitapların dünyasına verdiğini aktarır. Orada kendisine yeni dünyalar var eder. Kitapların onu kurtaran gemiler kayıklar olduğunu söyler.

\subsection{3. Tarihî Olaylar}

Romanda, tarihî olaylar da önemli yer tutar ve Dersim 1938, bunlardan en önemli olanıdır. Hatta bu konu, romanın temel sacayaklarındandır. O gün yaşananlar, romanda ayrıntısıyla anlatılır. Anlatıcı, 1938 için şunları söyler: "Kimliğimiz, 38 hamuruyla yoğrulmuş/Kamiya ma ebe mirê hirıs u heşti vıraziya" (Çiya, 2001: 38). Bu olaylar, peşi sıra dile getirilir. Anlatıcı, bunları anlatmakla kendisini mükellef görür: "Tarihe borçluyuz/Ma tarıxi rê dêndarime" (Çiya, 2001: 38). Kendisini, tarihe ve 1938 'de yaşayan insanlara borçlu hisseden anlatıcı, o günleri, çeşitli kişiler ve olaylar üzerinden ayrıntısıyla aktarmaya çabalar. Bu konu hem anlatıcı hem de Dersimliler için o kadar önemlidir ki romanda şu sözlere yer verilir: “Bizim içinse dünya 38'de değişmeye/yeni bir evreye geçmeye başlar/Ê ma ki dem u dewrê ma hirıs u heşti de vuriyo" (Çiya, 2001: 39). 1938, onlar için bir milattır. Artık Dersimliler için 1938'den öncesi ve sonrası vardır. Bu milat, günümüz insanları için de geçerlidir. Anlatıcı, kendi bölgesindeki çocukların, belli bir yaşa geldikten, çevrelerine anlam vermeye başladıktan sonra, 1938'i dillerine dolamaya başladıklarını ifade eder. Bu çocuklar, tarlaları, ovaları gezdikten, hayvanları otlattıktan, kısacası her ne yaparlarsa yapsınlar ondan sonra, konuyu 1938'e bağlarlar; çünkü her yerde onun anısına rastlarlar. 1938, halen sıcaktır ve günümüz gençlerinin zihnini yoğurmaktadır. Eserde, bu konunun nasıl işlendiğine daha yakından bakılabilir.

Romanda, yaşlıların 1938'den yani Dersim olaylarından bahsettiğine tanıklık edilir. Bu bahsediş anında korku, açlık, soğukluk, dinleyen herkesi sarmalar. Çaresizlik herkesin gözlerine siner ve bu şekilde gözler, uzaklara, boşluğa dalıp gider. Uzaklık düşüncesi, onları ürküten öteki şeydir. Çünkü akıllarına sürgünü getirir. O yıllarda yaşanan sürgünlerin kötü anıları, yaşanmışlıkları halen akıllarındadır. Yazar, söz konusu dönemin insanları için şunları dile getirir: "Önleri, çaresizlik ve bilgisizlik; arkaları ise korkuydu. Arkalarına bakmaktan korkuyorlardı; Dumanlar yükseliyor, etrafında dönüp dağ yamaçlarına ulaşıyordu... Yaşlılar nefes alamıyordu/Vırêniya xo beçarêni u nêzanaêni, peyniya xo ters u xof bi. Tersêne ke xo pey de niaderê. Dü dariyêne we, dormê xode ta diyêne biyêne berz, restêne gılê kou... Khal u kokımi ro, nêverdêne ke helme bıcêre " (Çiya, 2001: 8). Köylerin yakılması, insanların sürgüne gönderilmesi, Dersim'de yaşanan gerçek olaylardır. Dersim katliamını bizzat yaşamış olan Fatma Albayrak şunları anlatır: "Bir hafta sonra askerler yine geldi. Evlerimizi ateşe verdi. Annem o gün doğurmuş kardeşimi. Bebek bir 
günlük... Askerler saklandığımız ormanı da ateşe verdi. Biz kaçarken, annem kucağındaki bebekle yere düştü. Asker ateş etti, kurşun annemin sırtından girmiş, kucağındaki bir günlük bebeğimizin karnından çıkmıştı" (Doğan, 2012: 242). Ifade edildiği gibi romanda, o dönemin insanlarının sürgüne tabi tutuldukları ve evlerinin, tarlalarının yakıldığı ayrıntısıyla dile getirilir. Köylüler, günlerce asker süngüleri altında yürütülürler. Bu nakil esnasında, açlık baş gösterir. Küçük çocukların buna dayanacak gücü kalmaz. Üç dört yaşındaki bir çocuk günlerce aç kaldığı için önünde ekmek yiyen askerin eline atılır ancak bunda başarılı olamaz. Bazı sürgünlerin sonu ölümdür. Verilen emre göre köylüler, belli bir yere kadar götürülecek ve orada kurşunlanıp öldürüleceklerdir. Burada yazar, sadece ölümlerin değil, gaspın da olduğunu ifade eder. Nakil esnasında, askerler kendi aralarında konuşurlar. Köylüleri kurşundan geçirdikten sonra toprağın altına atmama kararı alırlar; çünkü onların üzerlerinde altın olduğunu ve onları almaları gerektiğini düşünürler. Hatta kendi aralarında paylaşıma dahi giderler: "Kimse unutmasın, parmak yüzükleri benimdir/Hama kes xovira mekero, iştanê bêçıke ê mınê" (Çiya, 2001: 98). Gasp olayı da Dersim'de yaşanan hadiselerdendir. Katliama bizzat katılmış olan A. Demirtaş, şunları aktarır: "Köylüleri topluyorduk. Bir araya getirip, 'sizi koruyacağız, kurtaracağız' diyerek dere kenarlarına veya uygun gördüğümüz yerlere götürüp makineli tüfeklerle tarıyorduk... Daha sonra erler, cesetlerin başlarına kurtlar gibi üşüşüyorlardı. Kollarını sıvazlayıp bilezik, kolye gibi ziynet eşyasını kapmak için hırslı bir yarış başlıyordu. Kadınlar için altın takmanın önemi büyük olduğundan kolları parçalanarak, kesilerek altınlar kapışılıyordu. Hatta altın dişler bile sökülüyordu” (Bulut: 2013: 345). Öte yandan romanda, mağaralarda öldürülen insanlardan da söz edilir.

Bu mağaralarda yüzlerce kişi öldürülmüştür. Bazılarının içine dinamit, bomba atılmış, bazıları da silahla taranmıştır. Ancak bu olaylarda gerçekleșen bir mucize de vardır. Yazar, küçük bir çocuktan bahseder. O, öldürülen onlarca kişinin içinde, sağ kalmayı başarmıştır. Ortalık durulduktan sonra annesinin göğsünü emer. Bu olay, birkaç gün sürer. Çocuk her acıktığında annesinin göğsünü emer. Günler sonra sağ kalan köylüler gelip bu çocuğu görünce büyük bir mucizeye tanıklık ederler. Mağaralarda yaşanan bu olaylardan dolayı, birçok mağaranın ismi sonradan değişir ve ölümleri anımsatan yeni isimler verilir. Romanda, mağaralarda yaşanıldığı söylenen olaylar, reel tarihe dayanır. Katliam döneminin önemli kişilerinden olan, daha sonra dışişleri bakanlığı da yapan ve Seyit Rıza'nın idamına bizzat katılmış olan ìsan Sabri Çağlayangil şunları aktarır: “... Neticeyi söylüyorum. Bunlar kabul etmediler. Mağaralara iltica etmişlerdi. Ordu zehirli gaz kullandı. Mağaraların kapısının içinden. Bunları fare gibi zehirledi. Yediden yetmişe o Dersim Kürtlerini kestiler. Kanlı bir hareket oldu. Dersim davası da bitti. Hükümet otoritesi de köye ve Dersim'e girdi. Dersim böyle bitti..."(Hür, 18.11.2012). Köy meydanında öldürülen kişilerin ise meydanda bırakıldıkları ve yabani hayvanların onları yedikleri bilgisine yer verilir. Genç kızlardan da söz edilir. Yeni gelinler, genç kızlar tecavüzlere uğrarlar. Kimi 
tecavüze uğramadan kendisini uçurumlara atarken kimi de tecavüzden kaçamaz ancak ondan sonra canına kıyar. Bu ve benzeri birçok olaya eserde, yer verilir.

Yaşanan acılar, Dersim halkının yaşamının birçok yerine sirayet etmiştir. Onun etkisini, birçok alanda görmek mümkündür. Bunlardan biri de halk arasında on yıllardır dillendirilen, kuşaktan kuşağa aktarılan ağıtlardır. Yazar, onlardan birine eserinde yer verir:

“Anam, anam, anam! / Daê, daê, daê

Ah kimsesizim / Bêkesa mı, wae

Felek kıymış / Felek qemiş biyo

Kara topraklara gitmiş / Şiya hardo şiaye

Ben ve evim yıkıldık / Ezo çê rıjiaye

Dersim'in önünden gidiyor / Dêrsım vera sona

Mameki'ye yurdudur / Welat Mamekiya

Anne konuș! / Daê qesey bıke

Neler çektin / To çı diya, nêdiya

Neden küskünsün? / Çıra herediya?

Diyor 38'dir / Vana, hirıs u heșto

Sonrası açlıktır / Têpia vêsaniya

Oğlum neden soruyorsun / Lacê mı çı pers kena

Bizim gördüğümüzü kimse görmedi / Awa ke ma diya, keşi nêdiya

Ömrümüz tükendi / Omrê ma qediya" (Çiya, 2001: 42-43).

Bu ağıt, Dersim olaylarının birçok örneğine yer verir. Öldürülen anneleri; yıkılan, yakılan köyleri; çekilen açlık ve susuzlukları dile getiren bir ağıttır.

\subsection{4. Romanın Masalımsı Atmosferi ve Halk Edebiyatı Unsurları}

Romanda, masalımsı bir atmosfer hâkimdir. Daha romanın başlarında yazar eserini, bir masal gibi yazacağını vurgular: "Bizim oralarda, geçip giden şeyler, bir masal olarak dile gelir/bir masal dile getirir. Ben de o yolu kendi gözümün önüne getirdim/Hetê made çiyo ke vêrdo ra şiyo, jê sanıke ardêne zon. Mı ki a rae guret xo çım” (Çiya, 2001: 6). Yaşadığı bölgede insanlar yaşadıklarını, duyduklarını, çok eski insanların tecrübe ettiği konuları, bir masal gibi dilden dile dolaştırırlar. Halk, anlattığı, tasvir ettiği bu olaylara kendisinden de bir şeyler 
katar ve onları kendi inançları, yaşam biçimleriyle süsler. Masalımsı öyküleme, başka sözlerle de desteklenir: "Kışın, uzun gecelerde, hepimiz ocağın önünde toplanıp masallar dinlerdik... Masal başladığı gibi her şeyi unutup kendimizi kaybederdik... Eski masallar, kişiyi, kanatları altına alıp gezdirirdi. Bazen Kaf dağına bazen de yerin yedi kat altına götürür sonra geri getirirdi/Zımıstani, sewunê dergu de ma pêro-pia verê locıne de niştêne ro, sanıki gosdêne... Hama, sanıke ke dest kerd $\mathrm{Cl}$, ma her çi xovira kerdêne şiyêne... Sanıkê khani, mordemi guretêne bınê perrunê xo, berdêne fetelnêne, vetêne 'ro koê Qafi ser, ya ki estêne hawt qat bınê hardi, reyna peyser ardêne” (Çiya, 2001: 12). İnsanların, masalın kanatları altına girdiği; masalın, onları kendi etkisi altına aldığı uzun kış geceleri, tüm bireyler birer masal kahramanı olurlar. Anlatılan söylencelerin dünyasını soluyan bireyler, başka âlemlere dalıp kısa süreliğine de olsa mekânsal bir değişim yaşarlar.

Masal dünyasına daldırılan bireyler, bazen Kaf dağında bazen de yerin yedi kat altında kendilerini bulurlar. Bu iki unsur, romanın masalımsı atmosferi için önemlidir; çünkü bu yerler, birçok masalda kendisine yer bulur. Örneğin Kaf dağı, masallarda uzağı ifade eden bir semboldür. Uzak ve yorucu yola giden masal kahramanı genellikle Kaf dağını aşmak zorundadır (Ercilasun, 1997: 137). Öte yandan, masallarda kahraman, düşmanın yurduna gidip oradaki düzeni alt üst etmelidir. Bu yer de ya yedi kat yerin altında, ya da gökyüzündedir (Bayat, 2005: 99). Masalların önemli noktalarından olan yerin ve göğün yedi kat olması motifi, romanın başka bir yerinde de işlenir. Bu ikinci motif, Minas isimli karakterden hareketle işlenir.

Minas isimli karakterin çizimi, masalımsı özellikleri barındırır. Zaten ondan bahsedilirken masallara, halk anlatılarına göndermelerde bulunulur. Minas'ın en büyük zevki, köyün dışında kurduğu devasa bahçesiyle ilgilenmektir. Çeşit çeşit ağaçların, otların, sebzelerin yetiştiği bu bahçe, adeta masal dünyasındaki bahçeleri andırır. Zaten yazar, "yedi kat gökten, yedi kat yer altından bir cennet meydana getirmişti/xorê hawt qat serê asmeni ra, hawt qat bınê hardi ra ju cenet ardi bi meydan" (Çiya, 2001: 57) sözleriyle bunu doğrudan dile getirmiş olur. Onun bahçesi ve yaptıkları, dilden dile dolaşır ve çok uzak beldelerin insanları dahi artık onlardan bahsederler. Yazar, "Minas değișiyordu, bir efsane oluyordu/Minas vuriyêne, biyêne ju efsane" (Çiya, 2001: 57) sözleriyle onun şanının ne boyutlara ulaştığını ortaya koyar. Çok uzak diyarlardaki insanlar, ondan bir Pir olarak bahsetmeye başlarlar. İnsanlara göre Minas, ağaçlarla konuşmaktadır. Ağaçlar onun talebesi, arkadaşı, o da onların Piri olmuştur. Minas'ın bir efsane olması, doğaüstü güçlere sahip dini bir kimliğe bürünmesi ve bir masal gibi, efsane gibi dilden dile dolaşması, romanın masalımsı yapısını destekler.

Kırk gün kırk gece süren düğün, masalların önemli motiflerinden biridir. Romanda, buna da yer verilir. Özellikle yeni yıla girilen günlerde, köye neşe hâkim olur. Çeşitli etkinliklerle hem toplumsal bağlar güçlendirilir hem de yaşam daha 
mutlu hale getirilmeye çalışılır. Yazar, bu neşeli etkinlikleri, masallardaki kırk gün kırk gece süren düğünlerdeki etkinliklere benzetir. Masallardaki kadar neşeli ve mutlu olduklarını vurgular (Çiya, 2001: 55).

Eserde, halkın kutsal atfettiği bölgelere de yer verilir. Türbeler, kiliseler, kutsal alanlar, masalımsı ve büyüleyici bir atmosferde dile getirilirler. Bu yerler hakkında birçok halk anlatısı vardır. Bunlardan biri, halkın kutsiyet atfettiği "Kırk Atlı" bölgesidir. Bu yerin, kendi tarihi içinde, mucizevî olayları barındırdığına inanılır. Bizans döneminde, askerler, bugünkü Dersim bölgesine akın ederler. Halk büyük bir korku ile dağlara doğru kaçmaya başlar. Askerler ise gaddarca sağa sola saldırırlar. Bu esnada aniden, gökyüzünden, güneş ışınları arasından 40 atlı belirir. Atlılar, Bizans ordularına saldırırlar ve onları püskürtürler. Bu olaylardan sonra, zifiri bir karanlık bölgenin üstüne çöker. Belli bir süre sonra karanlık dağılıp yerini aydınlığı bırakır. Köylüler, atlıları görmek için merakla sağa sola baksalar da kimseyi göremezler. Sadece kendi köylerinden kırk gencin cesedini görürler. Bu yaşananları, yaratıcının bir mucizesi olarak değerlendirirler. Kendilerini, yeniden doğmuş gibi hissederler çünkü toplu kıyımdan kurtulmuşlardır. Ayrıca, bulundukları yeri, kurtuluş yerleri olarak gördükleri için ölülerini oraya gömme kararı alırlar. O günden sonra o bölgeye “Kırk Atlı” bölgesi denir ve ona kutsallık atfedilir (Çiya, 2001: 77). İnsanlar, oraya gidip kurbanlar keserler. Örneğin Yusuf isimli karakter doğduktan sonra babası, oraya gidip kurban keser. Ayrıca bu bölgede, tılsımlı bir pınardan söz edilir. Çok eskiden beri, bu pınarın suyu ne eksilir ne de artar. Belli bir oranda, sürekli olarak varlığını sürdürür. Köylüler bu yüzden onu, tılsımlı pınar olarak adlandırırlar.

Köyün dışında bulunan bir kiliseden de bahsedilir. Bu, halkın korku ve saygı ile yaklaştığı bir yapıdır. Buna, halk arasında anlatılan söylenceler neden olur. Söylenceye göre, vakti zamanında, birkaç kişi gidip kilisenin duvarını yıkmak ister. Ancak duvar yıkılmadığı gibi, o kişiler parçalanıp domuza döner. Çok uzun yıllardır anlatılan bu olaydan dolayı, halk, kiliseye yaklaşmaktan korkar (Çiya, 2001: 79). Sadece dini yapılar değil, halkın kutsiyet atfettiği ve birçok halk söylencesinde kendilerinden bahsedilen dini karakterlere de romanda rastlanılır.

Dini kişilerden biri Hızır'dır: “Her taraf beyaz olunca, Yaşlı Hızır akla gelirdi... Kar her tarafı kaplayınca yollar kapanırdı... Ama olsun, herkes kendisine yeterdi. Eğer yetmezse de bu kez Hızır imdada yetişirdi/Sıpela ke va, Xızıro khal amêne mordemi viri... Vore ke rınd her ca guret xo ver, ra u rêçi bıriyêne... Va bıbo, her kes xorê bes bi. Eke bes nêbi, nafa ke Xızır restêne hawar" (Çiya, 2001: 5). Hızır, halk arasında, yardıma muhtaçların imdadına koşan mucizevî biridir. Bütün ümitlerin ortadan kalktığı, çarenin kalmadığına inanıldığı anlarda Hızır'ın ortaya çıkıp yardım ettiğine inanıır (Ocak, 2007: 107). Halk anlatılarının bu önemli kişisi, eserde bilinen misyonuyla kendisine yer bulur.

Roman boyunca çok fazla dini karaktere yer verilir. Çünkü yazar, eserin geçtiği yeri yani Dersim bölgesini “Dervişlerin Toprağı” (Çiya, 2001: 38) olarak niteler. Dervişlerin toprağında geçen romanın, birçok dini nitelikli kişiye yer 
vermesi doğaldır. Hızır dışında, Lokman Hekim de romanda kendisine yer bulur. Köydeki bir şelaleden bahsedilir. 150 metre yükseklikteki bu şelale için yazar, binlerce mimarın bir araya gelerek bu güzellikte bir eseri var edemeyeceğini dile getirir. Ona göre, dünyada, bunun eşi olan ikinci bir şey yoktur ve bu şelale, insanların ömrünü uzatıyordur. Şelaleden bahsedilirken halk anlatılarında ve dini metinlerde dile getirilen kişilere göndermede bulunulur. Anlatıcıya göre, Sultan Süleyman, ömrünü bu şelalenin gölgesinde geçirmiş, kuşlarla burada konuşmuştur. Bu eşsiz yer Lokman Hekim'e ilham olmuştur ve o ilaçlarını burada üretmiştir (Çiya, 2001: 70). Şelaleden hareketle birçok mitolojik kişiye göndermede bulunulur. Hz. Süleyman'ın kuşlarla konuşması, Lokman Hekim'in her derde deva ilaçlar üretmesi gibi doğaüstü olaylar, bu yapı üzerinden esere serpiştirilir.

Hz. Âdem, Hz. Havva ve Tavus Meleği gibi isimlere de yer verilir. Romanın anlatıcısı; kişilerin, büyük yüklerin altından tek başına kalkamayacaklarını dile getirir. Hazreti Âdem'in, tek başına yaşayamadığını ve Tavus Meleği'nin gelip ona, yol gösterdiğini ifade eder (Çiya, 2001: 16). Tavus Meleği, Yezidilik inancının en önemli motiflerinden biridir. Yezidilik inancında, yaratıcı, dünyayı yarattıktan sonra, elini dünyadan çeker. Onun yerine Melek Tavus dünyayla ilgilenir. Melek Tavus, yaratıcının alter egosudur. $O$, yaratıcıyla bütünleşmiştir, onunla birdir (Yalkut, 2002: 43). Romanda, bu önemli motife de yer verilerek eserin, mitolojik, doğaüstü yönü artırılmaya çalışılır.

Çeşitli hayvanlara da yer verilerek, romandaki halk anlatıları, inançları konusu güçlendirilir. Bunlardan biri Dağ keçisidir. Dağ keçisi, Dersim bölgesinde Malê Xızıri olarak adlandırılır. Yani ona, Hızır'ın malı/davarı denir. Bu yüzden, insanlar arasında adeta kutsanan bir hayvandır (Işık, 2012: 12). Ona karşı çok dikkatli davranılır; çünkü Hızır'ın onu koruduğuna inanılır. Bu hayvana romanda yer verilir: "Dağ keçileri, aşağı inmezlerdi. Nereye bakarsan bembeyazdı/Malo pesk, Malê Xızıri kou ra nêamêne war. Zobi, to koti ra ke niada, sıpela bi” (Çiya, 2001: 6). Kışın çok soğuk olduğu günlerde, hayatın durduğu dile getirilirken hayvanlar âleminden de yararlanılır. Bu hayvanlardan biri de dağ keçisidir. Dağ keçileri de bu soğuktan etkilenir ve yaşam alanlarında pek gözükmezler. Yaşam alanlarında gözüktükleri vakitlerde de genelde onlara karışılmaz çünkü onlara kutsiyet atfedilmiştir. Onlar, Hızır'ın koruması altındadır. Bireyler, onlara zarar verdiklerinde, kendi başlarına da bir şeyin gelmesinden çekinirler. Öte yandan yazar, insanların bazı hayvanları küçümsediklerini ancak onların, bu şekilde yanlış yaptıklarını ifade eder. Ona göre, hayvanlar çok küçük görülmemeli ve onlara değer verilmelidir. Bu düşüncesini de kurdun zekası örneği üzerinden somutlaştırmaya çalışır. Kurt ile köpek karşılaştıklarında, köpek ulumaya başlar. Bunun üzerine, kurt yalancı bir kaçışa başlar. Köpek, kurdun kendisinden korktuğunu sanıp onun peşine takılır. Ancak bu bir tuzaktır. Kurt onu, kendi arkadaşlarının yanına, kurt sürüsüne çekmektedir. Köpek, sürünün içine girince, kurtlar tarafından parçalanır: "Bir dakika içinde köpekten bir parça bile 
kalmaz/Wertê ju deqa de kutıki ra thaba nêmendêne" (Çiya, 2001: 7). Kurt, sinsi bir planla avını avlar.

Romanda, bazı yerlerin büyüleyici, masalımsı tarzda sunulduğu dile getirilmişti. Bu yerlerden biri de köyde bulunan bir çeşmedir. Söylenceye göre çok eski zamanlarda, o bölgede yaşayan kişiler, yaylalara çıarlar. Onların, binlerce hayvanı vardır. Yaylalarda da binlerce çeşit bitki, ot bulunur. Yaylalara çıkıldıktan sonra, hayvanlar o kadar iyi beslenirler ki elde edilen süte yetişilemez. Bunun için yerin altından bir yapı kurarlar ve aşağılara doğru indirirler. Yapının ucunda da bir çeşme yapılır. Bahar suları gibi süt akar o çeşmeden. Çeşme günümüzde de varlığını korur ve onun, eski zamanlara tanıklık ettiğine inanılır (Çiya, 2001: 80).

Dersim bölgesinden bahseden ve halk anlatılarına yer veren bir eserde, olmazsa olmaz motiflerden biri de pepuk/guguk kuşudur. Bu romanda da pepuk kuşu kendisine yer bulur. Dersim'de öldürülenlerin ruhlarının, halen kendi içlerinde bulunduğu ve pepuk kuşu gibi feryat ettikleri söylenir (Çiya, 2001: 39). Bu benzetme ile pepuk kuşu romana sokulur. Onun, acıları dile getirildiğine inanılan feryadına göndermede bulunulur.

Nuh tufanı dile getirilen öteki konudur. Anlatıcı, Almanya'da işe giderken tramvaya binerken topluluklarda bulunurken binlerce dile denk geldiğini söyler. Bu anlarda, kendi diline denk gelip gelmeyeceğine merak ettiğini ve konuşmalara kulak kabarttığını ifade eder. Ancak kendi dilinden tek kelime duymaz. Bu durumu, Nuh tufanına benzetir. Onun için sanki Nuh tufanı olmuştur ve kendi dilini konuşan tüm insanlar, orada can vermişlerdir (Çiya, 2001: 11). Bu anlarda bunaldığını ve kendisini kitapların dünyasına verdiğini aktarır.

\section{Sonuç}

Sait Çiya, Her Çi Beno Sanıke romanında alışılmışın dışında bir kurgusal yapıya başvurur. Roman, iki sesin çeşitli konulardaki diyalogları üzerine kurulmuştur. Bu yönüyle eser, Ferit Edgü'nün Kimse ile Jêhatî Zengelan'ın Zifqêra Berî (Bu roman, Çiya'nın romanından daha sonra yayımlanmıştır) adlı eserlerini akla getirir. Çiya'nın romanında, iki ses, sürekli olarak bir çatışma içindedirler. íkinci ses, ilk sesin benliğinin öteki kısmı, bilinçaltı şeklinde yorumlanabilir. Bütün insanlar, birçok konuda çeşitli düşünceler arasında gidip geldikten sonra kararlarını verirler. Öteki sesin, bilincin farklı alternatifler/düşünceler sunan öteki kısmı olduğu dile getirilebilir. Öte yandan bu sesin, toplumda, yazar gibi düşünmeyen kişilerin temsilcisi olduğu da ifade edilebilir. Ancak net bir şey söylenemez ve bu konu muallaktır.

Romana tematik açıdan yaklaşıldığında ise ilk olarak sürgünlük temi dikkati çeker. Daha romanın ilk cümlesinde yabancılık psikolojisi ile bunalmak üzere olan roman karakteriyle karşılaşılır. Sürgünlüğün yol açtığı depresif duygular baş edilemeyecek boyuta ulaşmış ve Almanya, nefes almayı güçleştiren, baş edilmesi güç yabancılık hisleri pompalayan bir dehlize dönmüştür. Anadile özlem, romanın 
öteki önemli konularından biridir. Karakter, dili, kişinin vatanı olarak tanımlar ve kendisinin, dilini konuşma imkânına sahip olmadığını belirterek vatansızlığın pençesine düştüğünü vurgular. 1938'de Dersim'de yaşananlar ise hemen hemen tüm boyutlarıla eserde işlenir. Öte yandan roman, masalımsı bir atmosfere sahiptir ve Kaf dağı; yerin ve göğün yedi kat olması; kırk gün kırk gece süren etkinlikler; Hızır; Lokman Hekim; Tavus Meleği; pepuk/guguk kuşu gibi masalların, halk anlatılarının önemli motiflerine eserde yer verilir.

\section{Kaynakça}

Aytaç, G. (2009). Genel Edebiyat Bilimi. İstanbul: Say yayınları.

Bayat, F. (2005). Mitolojiye Giriş. Çorum: KaraM yayınları.

Bulut, F. (2013). Dersim Raporları. İstanbul: Evrensel yayınları.

Çiya, S. (2001). Her Çi Beno Sanıke. İstanbul: Tij Yayınları.

Doğan, Y. (2012). Savrulanlar Dersim. İstanbul: Kırmızı Kedi yayınları.

Eagleton, T. (2011). Edebiyat Kuramı/Giriş, çev. T. Birkan. İstanbul: Ayrıntı yayınları. Edgü, F. (2006). Kimse. İstanbul: Sel yayınları.

Ekşi, A. (2002). "Sığınmacı ve Göçmenlerde Psikopatoloji”, Türk Psikiyatri Dergisi, 13(3): 215-221.

Ercilasun, B. (1997). Yeni Türk Edebiyatı Üzerine Incelemeler I. Ankara: Akçağ yayınları.

Hür, A. (2012). ). "Seyit Rıza İdamdan Önce Atatürk'le Görüştü mü?”, Radikal gazetesi, 18.11.2012 (http://www.radikal.com.tr/yazarlar/ayse-hur/seyit-rizaidamdan-once-ataturkle-gorustu-mu-1108301/, erişim tarihi 29.08.2017).

IŞIK, Y. (2012). Tunceli Folklorü. Ankara: Anıt Matbaa (Tunceli Valiliği öncülüğünde hazırlanan bir kitaptır).

Karasu, B. (2006). “Dehlizde Giden Adam”, Göçmüş Kediler Bahçesi. İstanbul: Metis yayınları.

Ocak, A. Y. (2007). İslam-Türk İnançlarında Hızır Yahut Hızır-ilyas Kültü. İstanbul: Kabalcı yayınları.

Said, E. (2009). Entelektüel/Sürgün, Marjinal, Yabancı, çev. T. Birkan. İstanbul: Ayrıntı yayınları.

Sartre, J. P. (2005). Edebiyat Nedir?, çev. B. Onaran. İstanbul: Can yayınları.

Tezcan, M. (2000). Dış Göç ve Eğitim. Ankara: Anı Yayıncılık

Yalkut, S.B. (2002). Melek Tavus'un Halkı Ezidiler. İstanbul: Metis yayınları.

Zengelan, J. (2009). Zifqêra Berî. İstanbul: Vate yayınları. 